\title{
PENGARUH MEDIA AUDIO VISUAL TERHADAP PRESTASI BELAJAR MURID PADA MATA PELAJARAN BAHASA INDONESIA KELAS V SD INPRES KELAPA TIGA 1 MAKASSAR
}

\author{
Dzulfadli S, Syafruddin, Haslinda. \\ Pendidikan Guru Sekolah Dasar, Fakultas Keguruan dan Ilmu Pendidikan \\ Universitas Muhammadiyah Makassar \\ Iqramsyar34@gmail.com
}

\begin{abstract}
ABSTRAK
Tujuan penelitian ini adalah untuk mengetahui pengaruh media audio visual terhadap prestasi belajar murid pada mata pelajaran bahasa Indonesia kelas V SD Inpres Kelapa Tiga 1 Makassar. Jenis penelitian ini adalah penelitian pra eksperimen dengan menggunakan desain one-group pretest-posttest design, yaitu penggunaan pre-test sebelum diberi perlakuan dan melakukan tes prestasi belajar pada post-test (setelah perlakuan). Subjek dalam penelitian ini adalah murid kelas V SD Inpres Kelapa Tiga 1 Makassar. tahun pelajaran 2016/2017 yang berjumlah 27 orang. Teknik pengumpulan data menggunakan tes. Teknik analisis data menggunakan uji $t$ test. Metode yang gunakan dalam penelitian ini adalah metode kuantitatif. Adapun hasil yang diperoleh sebagai berikut. Pengaruh prestasi belajar murid sebelum diberikan perlakuan (pre-test) yaitu dari 27 siswa terdapat 10 siswa $(37,03 \%)$ yang tuntas dan 17 (62,92\%) yang tidak tuntas. Skor rata-rata pre-test yaitu 63,33 berada pada kategori sedang. Setelah diberikan perlakuan dari 27 siswa terdapat 7 $(25,92 \%)$ yang tidak tuntas dan $20(74,07 \%)$ yang tuntas. Skor rata-rata post-test 73,59 berada pada kategori tinggi. Berdasarkan hasil penelitian tersebut di atas, dapat disimpulkan bahwa "media audio visual film berpengaruh terhadap prestasi belajar bahasa Indonesia murid kelas V SD Inpres Kelapa Tiga 1 Makassar" tahun Pelajaran 2016/2017. Terbukti dari hasil uji t yang memperoleh nilai $t$ hitung $>t$ tabel yaitu 10,29 $>1,70$ diterima. Artinya terdapat perbedaan skor rata-rata prestasi belajar murid sebelum dan sesudah menerapkan media audio visual yaitu sebelum diberi perlakuan 63,33\% sedangkan setelah diberi perlakuan $73,59 \%$.
\end{abstract}

Kata kunci : audio visual; prestasi belajar murid 


\section{PENDAHULUAN}

Belajar adalah suatu proses yang kompleks yang terjadi pada diri setiap orang sepanjang hidupnya. Proses belajar itu terjadi karena adanya interaksi antara seseorang dengan lingkungannya. Oleh karena itu, belajar dapat terjadi kapan saja dan dimana saja. Apabila proses belajar mengajar itu diselenggarakan secara formal di sekolah-sekolah, tidak lain ini dimaksudkan untuk mengarahkan perubahan pada diri siswa secara terencana, baik dalam aspek pengetahuan, ketrampilan, maupun sikap. Interaksi yang terjadi selama proses belajar tersebut dipengaruhi oleh lingkungannya, yang antara lain terdiri atas murid, guru, petugas perpustakaan, kepala sekolah, bahan atau materi pelajaran (buku, modul, selebaran, majalah, rekaman video atau audio dan yang sejenisnya).

Proses pembelajaran di kelas menjadi tumpuan diperolehnya lulusan yang tidak hanya mampu menguasai pengetahuan, namun juga diharapkan memiliki sikap dan keterampilan yang memadai. Untuk mencapai lulusan yang berkualitas dalam berbagai hal baik sikap, pengetahuan, maupun keterampilan maka disusunlah kurikulum pada setiap jenjang pendidikan yang terdiri dari beberapa mata pelajaran dan diharapkan dapat menunjang kompetensi lulusan. Bahasa Indonesia merupakan salah satu dari sekian banyak mata pelajaran yang diajarkan di sekolah dasar/madrasah ibtidaiyah. Tujuan pembelajaran bahasa Indonesia secara umum adalah mengembangkan keterampilan siswa dalam menggunakan bahasa, baik untuk kemampuan menyimak, berbicara, membaca, maupun menulis.

Dikalangan pendidik tradisional kata media selama ini sering terkesan sesuatu yang mahal, rumit, dan berteknologi tinggi. Akibatnya terjadi keengganan berhubungan dengan media meskipun sebenarnya di sekolah sudah terdapat sarana pembelajaran bahasa yang memadai akan tetapi tidak dimanfaatkan dengan baik dan maksimal.

Perubahan paradigma dalam proses pembelajaran dari teacher centered ke student centered, dari passive learning ke active learning, penggunaan media juga merupakan alat bantu bagi guru sehingga siswa lebih mudah dalam memahami isi atau pesan yang terkandung dalam suatu mata pelajaran, apalagi bagi anak usia sekolah dasar yang dalam perkembangannya masih berada dalam tahap operasional 
kongkrit. Keberadaan media pembelajaran akan sangat membantu belajar anak-anak diusia tersebut.

Menurut Rohani (1997: 97-98) "penggunaan media audio visual dalam pembelajaran sangat memungkinkan untuk meningkatkan kemampuan berpikir yang diharapkan". Kelebihan yang dimiliki oleh media tersebut dapat mempersiapkan sumber daya manusia melalui pendidikan yang berkualitas. Melalui media audio visual diharapkan ada peningkatan dalam proses pembelajaran bahasa Indonesia, terutama dalam hal peningkatan prestasi belajar siswa.

Berdasarkan pendapat di atas dapat disimpulkan bahwa media audio visual adalah alat bantu berupa fisik maupun nonfisik yang sengaja digunakan sebagai perantara antara guru dan siswa dalam memahami materi pembelajaran agar lebih efektif dan efisien, yang berupa program video/televisi pendidikan maupun slide suara, sehingga meteri pembelajaran lebih cepat diterima siswa dengan utuh serta menarik minat siswa untuk belajar lebih lanjut.

Berdasarkan uraian di atas rumusan masalah dalam penelitian ini adalah: "Apakah ada Pengaruh Media Audio Visual terhadap Prestasi Belajar Murid pada Mata Pelajaran Bahasa Indonesia Kelas V SD Inpres Kelapa Tiga 1 Makasaar”. Adapun tujuan penelitian ini adalah untuk mendeskripsikan Pengaruh Penggunaan Media Audio Visual terhadap Prestasi Belajar Murid pada Mata Pelajaran Bahasa Indonesia Kelas V SD Inpres Kelapa Tiga 1 Makasaar.

\section{Media Audio Visual}

\section{a. Pengertian Media Audio Visual}

Kata media berasal dari bahasa Latin "medius" yang secara harfiah berarti, tengah", „perantara" atau „pengantar". Dalam bahasa Arab, media adalah perantara ( a atau pengantar pesan dari pengirim kepada penerima pesan.

Gerlach dan Ely (1971) mengatakan bahwa media apabila dipahami secara garis besar adalah manusia, materi, atau kejadian yang membangun kondisi yang membuat siswa mampu memperoleh pengetahuan, keterampilan, atau sikap. Dalam pengertian ini, guru, buku teks, dan lingkungan sekolah merupakan media. Secara lebih khusus, pengertian media dalam proses belajar mengajar cenderung diartikan sebagai alat-alat grafis, photographis, atau elektronis untuk menangkap, memproses, dan menyusun kembali informasi visual atau verbal. 
Dari beberapa pengertian di atas dapat kita garis bawahi bahwa media adalah perantara dari sumber informasi ke penerima informasi, contohnya video, televise, computer dan lain sebagainya. Alat-alat tersebut merupakan media manakala digunakan untuk menyalurkan informasi yang akan disampaikan. Media audio visual merupakan salah satu jenis media pembelajaran yang dapat digunakan dalam proses pembelajaran.

Asyhar (2011: 45) mendefinisikan bahwa media audio visual adalah “jenis media yang digunakan dalam kegiatan pembelajaran dengan melibatkan pendengaran dan penglihatan sekaligus dalam satu proses atau kegiatan. Pesan dan informasi yang dapat disalurkan melalui media ini dapat berupa pesan verbal dan nonverbal yang mengandalkan baik penglihatan maupun pendengaran. Beberapa contoh media audio visual adalah film,video, program TV dan lain-lain".

Berdasarkan penjelasan di atas dapat disimpulkan bahwa media audio visual merupakan media yang dapat digunakan dalam kegiatan pembelajaran dengan melibatkan pendengaran dan penglihatan sekaligus dalam satu proses atau kegiatan. Contoh media audio visual adalah film, video, program TV, slide suara (sound slide) dan lain-lain.

b. Langkah-langkah Audio Visual

Media pembelajaran audio visual memiliki langkah-langkah dalam penggunaannya seperti halnya media pembelajaran lainnya. Langkah-langkah pembelajaran menggunakan media audio visual adalah sebagai berikut.

1) Guru memahami materi/bahan ajar yang akan disampaikan.

2) Guru memilih media yang akan digunakan, bisa televise atau video cassette

3) Guru membuat media yang sesuai dengan materi/bahan ajar, media ini hendaknya memiliki suara yang dapat didengar oleh seluruh sisiwa dan gambar yang dapat dilihat oleh seluruh siswa.

4) Menyiapkan proses belajar.

5) Memastikan media berjalan sesuai dengan harapan.

6) Menyiapkan siswa kemudian menjelaskan kepada siswa apa yang harus mereka lakukan pada saat pembelajaran.

7) Setelah segala persiapan selesai baik dari siswa, media, bahan dan guru. Barulah guru memulai pelajaran. 
8) Guru mulai menggunkan media.

9) Setelah penyampaian materi selesai, guru bersama siswa secara bersama mengulas kembali materi yang telah dipelajari bersama kemudian menyimpulkan.

\section{Prestasi Belajar}

a. Pengertian Prestasi Belajar

Menurut Purwodarminto prestasi ialah hasil sesuatu yang telah dicapai. (1977: 251). Menurut Hilgard (1984: 252) belajar merupakan proses perbuatan yang dilakukan dengan sengaja kemudian menimbulkan perubahan yang keadaannya berbeda dari perubahan yang ditimbulkan oleh lainnya. Slameto (2003: 10) menyatakan bahwa prestasi belajar merupakan suatu perubahan yang dicapai seseorang setelah mengikuti proses belajar. Perubahan ini meliputi perubahan tingkah laku secara menyeluruh dalam sikap, keterampilan dan pengetahuan.

Dari definisi tersebut dapat disimpulkan bahwa pengertian dari prestasi belajar ialah hasil usaha, bekerja atau belajar yang menunjukkan ukuran kecakapan yang dicapai dalam bentuk nilai.

\section{Hakikat Pembelajaran Bahasa Indonesia}

Bahasa Indonesia ialah bahasa rasmi Republik Indonesia sebagaimana disebutkan dalam Undang-Undang Dasar RI 1945, Pasal 36. Ia juga merupakan bahasa persatuan bangsa Indonesia sebagaimana disebut dalam Sumpah Pemuda 28 Oktober 1928.

Menurut Keraf (2005:1), memberikan dua pengertian bahasa. Pengertian pertama menyatakan bahasa sebagai alat komunikasi antara anggota masyarakat berupa simbol bunyi yang dihasilkan oleh alat ucap manusia. Kedua, bahasa adalah sistem komunikasi yang mempergunakan simbol-simbol vokal (bunyi ujaran) yang bersifat arbitrer.

Menurut Tarigan (1989:4), beliau memberikan dua definisi bahasa. Pertama, bahasa adalah suatu sistem yang sistematis, barang kali juga untuk sistem generatif. Kedua, bahasa adalah seperangkat lambang-lambang mana suka atau simbol-simbol arbitrer.

Menurut Santoso (1990:1), bahasa adalah rangkaian bunyi yang dihasilkan oleh alat ucap manusia secara sadar. Mackey (1986:12), bahasa adalah suatu bentuk dan bukan suatu keadaan (lenguage may be form and not matter) atau sesuatu sistem 
lambang bunyi yang arbitrer, atau juga suatu sistem dari sekian banyak sistem-sistem, suatu sistem dari suatu tatanan atau suatu tatanan dalam sistem-sistem. Sejalan dengan itu, menurut Wibowo (2001:3), bahasa adalah sistem simbol bunyi yang bermakna dan berartikulasi (dihasilkan oleh alat ucap) yang bersifat arbitrer dan konvensional, yang dipakai sebagai alat berkomunikasi oleh sekelompok manusia untuk melahirkan perasaan dan pikiran.

\section{METODE PENELITIAN}

Jenis penelitian ini adalah penelitian eksperimen, yaitu metode penelitian yang digunakan untuk mencari pengaruh perlakuan tertentu terhadap yang lain dalam kondisi yang terkendalikan. Dalam penelitian ini di gunakan desain pra-eksperimen karena hanya melibatkan satu kelas sebagai kelas eksprimen yang dilaksanakan tanpa adanya kelompok pembanding. Desain penelitian yang akan digunakan dalam penelitian ini adalah One Group Pretest-Posttest Design.

Populasi dalam penelitian ini adalah siswa kelas V SD Inpres Kelapa Tiga 1 Makasaar, tahun ajaran 2016/2017 yang berjumlah 27 orang. Pada penelitian ini menggunakan sample total sampling yaitu pengambilan anggota sampel secara keseluruhan yaitu siswa kelas V SD Inpres Kelapa Tiga 1 Makasaar, tahun ajaran 2016/2017 yang berjumlah 27 orang. Untuk menganalisis data yang diperoleh dari hasil penelitian akan digunakan analisis statistik deskriptif dan inferensial.

\section{HASIL PENELITIAN DAN PEMBAHASAN}

Deskripsi Prestasi Belajar Pre - test Murid kelas V SD Inpres Kelapa Tiga 1 Makassar.

Berdasarkan hasil penelitian yang dilakukan oleh peneliti di SD Inpres Kelapa Tiga 1 Makasaar mulai tanggal Juli 8- 20 Juli 2016, maka diperoleh data-data yang dikumpulkan melalui instrumen tes sehingga dapat diketahui prestasi belajar murid berupa nilai dari siswa kelas V SD Inpres Kelapa Tiga 1 Makasaar.

Adapun deskripsi secara kuantitatif skor prestasi belajar Pre-test sebelum diberikan perlakuan (treatment) dapat dilihat pada tabel 4.1 berikut.

Tabel 1. Statistik Skor Prestasi Belajar pre - test siswa kelas V SD Inpres

Kelapa Tiga 1 Makassar. 


\begin{tabular}{|c|c|}
\hline Statistik & Nilai Statistik \\
\hline Jumlah murid & 27 \\
\hline Nilai ideal & 100 \\
\hline Nilai maksimum & 80 \\
\hline Nilai minimum & 40 \\
\hline Rentang nilai & 40 \\
\hline Nilai rata-rata & 63,33 \\
\hline
\end{tabular}

Berdasarkan tabel 4.1 menunjukkan bahwa skor rata-rata (mean) prestasi belajar murid kelas V SD Inpres Kelapa Tiga 1 Makassar setelah dilakukan Pre-test adalah 63,33 dari skor ideal yang mungkin dicapai adalah 100. Skor maksimum 80 dari skor ideal 100, skor minimum 40 dari skor ideal 100, dan rentang skor 40 dari skor ideal 100 yang mungkin di capai. Skor rata-rata tersebut menunjukkan bahwa prestasi belajar murid kelas V SD Inpres Kelapa Tiga 1 Makasaar dalam kategori sangat rendah.

Hal ini disebabkan karena masih kurangnya perhatian murid terhadap materi pelajaran yang diajarkan. Apabila skor hasil belajar murid dikelompokkan kedalam 5 kategori maka diperoleh distribusi frekuensi nilai seperti yang disajikan pada tabel 4.2 .

Tabel 2. Statistik Frekuensi dan Persentase Skor Prestasi Belajar Pre-test

\begin{tabular}{|c|c|c|c|c|}
\hline No & Skor & Kategori & Frekuensi & Persentase \% \\
\hline 1 & $0-40$ & Sangat rendah & 2 & $7,40 \%$ \\
\hline 2 & $45-55$ & Rendah & 4 & $14,81 \%$ \\
\hline 3 & $60-75$ & Sedang & 11 & $40,74 \%$ \\
\hline 4 & $76-80$ & Tinggi & 10 & $37,03 \%$ \\
\hline 5 & $85-100$ & Sangat tinggi & - & - \\
\hline \multicolumn{3}{|c|}{ Jumlah } & 27 & 100 \\
\hline
\end{tabular}

Berdasarkan tabel 4.2 diperoleh bahwa dari 27 orang jumlah murid kelas V SD Inpres Kelapa Tiga 1 Makasaar, terdapat 2 murid $(7,40 \%)$ yang berada pada kategori sangat rendah, 4 murid $(14,81 \%)$ yang berada pada kategori rendah, 11 murid $(40,74 \%)$ yang berada pada kategori sedang dan 10 murid $(37,03 \%)$ berada pada 
kategori tinggi dan belum murid ada yang berada pada kategori sangat tinggi karena belum mencapai KKM 70 . Hal ini disebabkan karena masih kurangnya minat dan prestasi belajar murid serta proses pembelajaran di dominasi oleh murid yang pintar saja.

Berdasarkan data hasil penelitian yang tercantum pada lampiran maka persentase ketuntasan prestasi belajar bahasa Indonesia murid kelas V SD Inpres Kelapa Tiga 1 Makassar pada prestasi belajar Pre-test dapat di lihat pada tabel 4.3 berikut.

Tabel 3 Deskripsi Ketuntasan Hasil Belajar Pre-test

\begin{tabular}{|c|c|c|c|}
\hline Persentase Nilai & Kategori & Frekuensi & $\begin{array}{c}\text { Persentase } \\
\text { (\%) }\end{array}$ \\
\hline$\leq 70$ & $\begin{array}{c}\text { Tidak } \\
\text { tuntas }\end{array}$ & 16 & $59,25 \%$ \\
\hline$\geq 70$ & Tuntas & 11 & $40,74 \%$ \\
\hline \multicolumn{2}{|c|}{ Jumlah } & $\mathbf{2 7}$ & $\mathbf{1 0 0}$ \\
\hline
\end{tabular}

Berdasarkan tabel 3 di atas maka dapat disimpulkan bahwa prestasi belajar murid kelas V SD Inpres Kelapa Tiga 1 Makassar setelah dilakukan Pre-test prestasi belajar bahasa Indonesia terdapat 16 murid (59,25\%) yang belum tuntas dan 11 murid $(40,74 \%)$ yang telah tuntas belajarnya. Ini berarti ketuntasan belajar tidak memuaskan secara klasikal karena nilai rata-rata 63,33 belum mencapai KKM yang diharapkan yaitu 70 .

\section{Deskripsi Prestasi Belajar Post - test Murid Kelas V SD Inpres Kelapa Tiga 1 Makassar.}

Selama penelitian berlangsung terjadi perubahan terhadap kelas setelah diberikan perlakuan. Perubahan tersebut berupa prestasi belajar yang datanya diperoleh setelah diberikan Post- test. Perubahan tersebut dapat dilihat dari data berikut ini.

Adapun deskripsi secara kuantitatif skor hasil belajar Post-test setelah diberikan perlakuan (treatment) dapat dilihat pada tabel 4.4 berikut. 
Tabel 4 Statistik Skor Hasil Belajar Murid Kelas

\begin{tabular}{|c|c|}
\hline Statistik & Nilai Statistik \\
\hline Jumlah murid & 27 \\
\hline Nilai ideal & 100 \\
\hline Nilai maksimum & 100 \\
\hline Nilai minimum & 60 \\
\hline Rentang nilai & 40 \\
\hline Nilai rata-rata & 73,59 \\
\hline
\end{tabular}

Berdasarkan tabel 4 menunjukkan bahwa skor rata-rata (mean) hasil belajar murid kelas V SD Inpres Kelapa Tiga 1 Makasaar setelah dilakukan Post-test adalah 73,59 dari skor ideal yang mungkin dicapai adalah 100. Skor maksimum 100 dari skor ideal 100, skor minimum 60 dari skor ideal 100, dan rentang skor 40 dari skor ideal 100 yang mungkin di capai. Skor rata-rata tersebut menunjukkan bahwa prestasi belajar bahasa Indonesia murid kelas V SD Inpres Kelapa Tiga 1 Makassar berada dalam kategori tinggi.

Hal ini disebabkan karena meningkatnya perhatian murid terhadap materi pelajaran yang diajarkan dengan menggunakan media audio visual. Apabila skor prestasi belajar murid dikelompokkan kedalam 5 kategori maka diperoleh distribusi frekuensi nilai seperti yang disajikan pada tabel 4.2.

Tabel 5 Statistik Frekuensi dan Persentase Skor Prestasi Belajar Post-test

\begin{tabular}{|c|c|c|c|c|}
\hline No & Skor & Kategori & Frekuensi & Persentase \% \\
\hline 1 & $0-40$ & Sangat rendah & - & - \\
\hline 2 & $45-55$ & Rendah & - & \\
\hline 3 & $60-75$ & Sedang & 7 & $25,92 \%$ \\
\hline 4 & $76-80$ & Tinggi & 15 & $55,55 \%$ \\
\hline 5 & $85-100$ & Sangat tinggi & 5 & $18,51 \%$ \\
\hline \multicolumn{3}{|c|}{ Jumlah } & 27 & 100 \\
\hline
\end{tabular}

Berdasarkan tabel 5 diperoleh bahwa dari 27 orang jumlah murid kelas V SD Inpres Kelapa Tiga 1 Makassar, terdapat 7 murid $(25,92 \%)$ berada pada kategori 
sedang, 15 murid (55,55\%) yang berada pada kategori tinggi, dan 5 murid (18,51\%) yang berada pada kategori sangat tinggi. Hal ini disebabkan meningkatnya minat dan perhatian belajar murid sehingga dapat memenuhi KKM yang ditentukan yaitu 70 .

Berdasarkan data hasil penelitian yang tercantum pada lampiran maka persentase ketuntasan prestasi belajar bahasa Indonesia murid kelas V SD Inpres Kelapa Tiga 1 Makassar pada prestasi belajar Post-test dapat di lihat pada tabel 4.6 berikut.

Tabel 6 Deskripsi Ketuntasan Prestasi Belajar Post-test

\begin{tabular}{|c|c|c|c|}
\hline Persentase Nilai & Kategori & Frekuensi & $\begin{array}{l}\text { Persentase } \\
\text { (\%) }\end{array}$ \\
\hline$\leq 70$ & $\begin{array}{r}\text { Tidak } \\
\text { tuntas }\end{array}$ & 7 & $25,92 \%$ \\
\hline$\geq 70$ & Tuntas & 20 & $74,07 \%$ \\
\hline \multicolumn{2}{|r|}{ Jumlah } & $\mathbf{2 7}$ & $\mathbf{1 0 0}$ \\
\hline
\end{tabular}

Berdasarkan tabel 6 di atas maka dapat disimpulkan bahwa prestasi belajar murid kelas V SD Inpres Kelapa Tiga 1 Makassar setelah dilakukan Post-test prestasi belajar bahasa Indonesia terdapat 7 murid $(25,92 \%)$ yang belum tuntas hasil belajarnya dan 20 murid (74,07\%) yang telah tuntas belajarnya. Ini berarti ketuntasan belajar memuaskan secara klasikal karena nilai rata-rata 73,59 telah mencapai KKM yang diharapkan yaitu 70 .

\section{Pengaruh Penggunaan Media Pembelajaran Audio Visual Terhadap Prestasi Belajar Bahasa Indonesia Murid Kelas V SD Inpres Kelapa Tiga 1 Makassar}

Sesuai dengan hipotesis penelitian yakni "penggunaan media pembelajaran audio visual memiliki pengaruh terhadap prestasi belajar bahasa Indonesia murid kelas V SD Inpres Kelapa Tiga 1 Makassar”. Maka teknik yang digunakan untuk menguji hipotesis tersebut adalah teknik statistik inferensial dengan menggunakan uji-t. (Tabel 4.7 terlampir)

Langkah-langkah dalam pengujian hipotesis adalah sebagai berikut :

1. Mencari harga "Md" dengan menggunakan rumus:

$$
\begin{aligned}
\operatorname{Md} & =\frac{\sum d}{N} \\
& =\frac{278}{27}
\end{aligned}
$$




$$
=10,29
$$

2. Mencari harga " $\sum X^{2} d "$ dengan menggunakan rumus:

$$
\begin{aligned}
\sum X^{2} d & =\sum d^{2}-\frac{\left(\sum d\right)^{2}}{N} \\
& =3581-\frac{(278)^{2}}{27} \\
& =3581-\frac{77284}{27} \\
& =3581-2862,37 \\
& =718,63
\end{aligned}
$$

3. Menentukan harga $t_{\text {Hitung }}$

$$
\begin{array}{ll}
\mathrm{t} & =\frac{M d}{\sqrt{\frac{\sum X^{2} d}{N(N-1)}}} \\
\mathrm{t} & =\frac{10,29}{\sqrt{\frac{718,63}{27(27-1)}}} \\
\mathrm{t} & =\frac{10,29}{\sqrt{\frac{718,68}{702}}} \\
\mathrm{t} & =\frac{10,29}{\sqrt{1,02}} \\
\mathrm{t} & =\frac{10,29}{1,00} \\
\mathrm{t} & =10,29
\end{array}
$$

4. Menentukan harga $\mathrm{t}_{\text {Tabel }}$

Untuk mencari $\mathrm{t}_{\text {Tabel }}$ peneliti menggunakan table distribusi t dengan taraf signifikan $\alpha=0,05$ dan $d . b=N-1=27-1=26$ maka diperoleh $\mathrm{t}_{0,05}=1,70$

Setelah diperoleh $\mathrm{t}_{\text {Hitung }}=10,29$ dan $\mathrm{t}_{\text {Tabel }}=1,70$, maka diperoleh $\quad \mathrm{t}_{\text {Hitung }}>\mathrm{t}_{\text {Tabel }}$ atau $10,29>1,70$. Sehingga dapat disimpulkan bahwa $\mathrm{H}_{0}$ ditolak dan $\mathrm{H}_{\mathrm{a}}$ diterima. Ini berarti bahwa penerapan media pembelajaran audio visual berpengaruh terhadap prestasi belajar murid pada mata pelajaran bahasa Indonesia kelas V SD Inpres Kelapa Tiga 1 Makassar.

Dari hasil penelitian sebelum dan sesudah digunakan media audio visual diketahui bahwa terjadi peningkatan prestasi belajar bahasa Indonesia setelah menggunakan media audio visual. Hasil ini dapat dilihat pada skor rata-rata prestasi belajar bahasa Indonesia kelas V SD Inpres Kelapa Tiga 1 Makassar dan hipotesis dinyatakan dapat diterima. 
Penerimaan hipotesis tersebut menunjukkan bahwa murid yang diberi pembelajaran dengan menggunakan media audio visual memiliki prestasi belajar yang lebih meningkat dibanding sebelum diberi perlakuan. Nilai rata-rata hasil prestasi belajar pada post-test mencapai 73,59, lebih tinggi dibandingkan pada pre-test yang hanya mencapai 63,33 .

Peningkatan prestasi belajar pada murid tersebut terjadi karena pada pembelajaran dengan menggunakan media audio visual, murid dalam kegiatan pembelajaran dengan melibatkan pendengaran dan penglihatan sekaligus dalam satu proses atau kegiatan.

Pesan dan informasi yang dapat disalurkan melalui media ini dapat berupa pesan verbal dan nonverbal yang mengandalkan baik penglihatan maupun pendengaran, sehingga anak termotivasi untuk meningkatkan proses belajar yang sedang berlangsung. Artinya penerapan media audio visual berhasil dan mencapai taraf sesuai dengan harapan dapat meningkatkan prestasi belajar murid.

Berdasarkan hasil analisis statistik inferensial dengan menggunakan rumus uji


26, pada taraf signifikansi $5 \%$ diperoleh $t_{\text {tabel }}=1,70$. Oleh karena $t_{\text {hitung }}>t_{\text {tabel }}$ pada taraf signifikansi 0,05 , maka hipotesis nol $\left(\mathrm{H}_{0}\right)$ ditolak dan hipotesis alternative $\left(\mathrm{H}_{\mathrm{a}}\right)$ diterima yang berarti penggunaan media pembelajaran audio visual mempengaruhi hasil belajar bahasa Indonesia.

Hasil analisis belajar bahasa Indonesia murid yang dijadikan sampel penelitian sebelum dan sesudah diberikan perlakuan, murid yang berada pada kategori sangat rendah setelah diberikan perlakuan lebih sedikit dibanding dari kategori sangat rendah sebelum diberikan perlakuan. Hal ini disebabkan dengan pengetahuan murid terhadap materi yang diajarkan sudah lebih dipahami dengan menggunakan media audio visual.

\section{SIMPULAN DAN SARAN}

Berdasarkan hasil penelitian di atas, maka dapat ditarik kesimpulan untuk jawaban pertanyaan dari rumusan masalah yaitu, "media audio visual berpengaruh terhadap prestasi belajar bahasa Indonesia murid kelas V SD Inpres Kelapa Tiga 1 Makassar" tahun Pelajaran 2016/2017. Terbukti dari hasil uji t yang memperoleh nilai t hitung > 
t tabel yaitu 10,29 > 1,70 diterima. Artinya terdapat perbedaan prestasi belajar murid sebelum dan sesudah menerapkan media audio visual. Nilai rata-rata rasa percaya diri anak setelah diberi perlakuan (post-test) mencapai 73,59, lebih tinggi dibandingkan sebelum diberi perlakuan (pre-test) yang hanya mencapai 63,33. Perbedaan tersebut menunjukkan bahwa penerapan media audio visual berpengaruh positif terhadap prestasi belajar bahasa Indonesia murid kelas V SD Inpres Kelapa Tiga 1 Makassar".

Saran yang dapat diberikan: (1) Disarankan kepada guru khususnya guru bahasa Indonesia agar menggunakan media manipulatif dalam pembelajaran agar pembelajaran dapat lebih menarik. (2) Untuk mempermudah dalam pencapaian kompetensi dasar diharapkan kepada guru untuk lebih mengoptimalkan penggunaan media dan memilih media yang relevan dengan pembahasan materi pelajaran. (3) Bagi peneliti yang berminat mengembangkan lebih lanjut penelitian ini, diharapkan mencermati keterbatasan penelitian ini, sehingga penelitian selanjutnya dapat menyempurnakan hasil penelitian.

\section{DAFTAR PUSTAKA}

Akhadiah, dkk. 1991. Tujuan Pembelajaran Bahasa Indonesia

Arifin, Zaenal. 1991. Evaluasi Intruksional Prinsip Teknik Prosedur. Bandung: Remaja Rosdakarya.

Arikunto, Suharismi. 2002. Prosedur Penelitian Suatu Pendekatan Praktek, edisi revisi V. Jakarta: Rieneka Cipta.

Arikunto, Suharismi. 2006. Rumus "T" One Group Pre-test dan post-tes.

Arsyad. 2011. Kelebihan dan Kelemahan Media Audio Visual.

Asyhar. 2011. Pengertian Media Audio Visual.

Danim, 2010. Pengertian film pendidikan

Ely dan Gerlach. 1971. Media Secara Garis Besar.

Erdaolivya. 2014. Pengertian Bahasa Indonesia.https://erdaolivya.wordpress.comDiak ses 12 Agustus.

Faesal, Sanafiah.2001. Pengertian Populasi.

Hamalik Oemar 1985. prinsip film

Indrasukmana. 2001. Pelaksanaan Tes secara Lisan maupun Tertulis 
Keraf. 2005. Pengertian Bahasa.

Purwanto. 2003. Pengertian dan Fungsi Prestasi Belajar.

Purwodarminto. 1977. Pengertian Prestasi Belajar.

Rabiger Michael (2009:8). Pengertian film.

Rianto. 2001. Pengertian Hipotesis.

Sabari, Ahmad. 2005. Strategi Belajar dan Mengajar. Jakarta: Quantum Teaching.

Sadiman. 2005. Pengertian Media.

Sanjaya, Wina. 2012 . Media Komunikasi Pembelajaran. Jakarta: Kencana Perdana Media Group.

Sialvianputranto. 2012. Langkah-langkah penggunaan Media dan Metode. http://sialvi anputranto.blogspot.co.id diakses 12 April.

Slameto. 1995. Belajar dan Faktor-faktor yang mempengaruhinya. Jakarta: Bina Aksara.

Soehartono, Irawan. 1995. Metode Penelitian Sosial. Bandung: Remaja Rosdakarya.

Sudjana. 2013. Media Pengajaran. Bandung : Sinar Baru Algensindo.

Sugiyono. 2013. Metode Penelitian Kuantitatif Kualitatif dan R \& D. Bandung: Alfabeta.

Sugiyono. 2015. Metode Penelitian Kuantitatif Kualitatif dan R \& D. Bandung: Alfabeta.

Sunartana PPn dan Nurkancana. 2005. Pengertian Metode Tes.

Syah. 2006. Faktor-faktor yang Mempengaruhi Prestasi Belajar.

Syamsudin dan Palapah (1986: 114). Mendefinisikan film. 